Striking at the Roots of Crime:

The Impact of Welfare Spending on Crime During the Great Depression

\author{
Price V. Fishback ${ }^{a}$, Ryan S. Johnson ${ }^{\text {b }}$, and Shawn Kantor ${ }^{c}$
}

\author{
${ }^{a}$ University of Arizona and NBER \\ ${ }^{b}$ Brigham Young University, Idaho \\ ${ }^{c}$ University of California, Merced, and NBER
}

November 2008

JEL Codes: K4, N31, N41, I38, H53

The authors wish to acknowledge the helpful comments of James Heckman, Lawrence Katz, Lars Lefgren, Paul Rhode, Koleman Strumpf, and an anonymous referee. We offer special thanks to Koleman Strumpf for providing us with information on the extent to which Prohibition was repealed by local governments and Paul Rhode who shared annual data on tax returns with us. Seminar participants at the 2002 NBER Summer Institute, 2003 ASSA meetings, and the Universities of California-Davis, California-Los Angeles, California-Riverside, and Utah provided insightful comments and advice. Financial support has been provided by National Science Foundation Grants SBR-9708098, SES0080324, and SES-0214395. We are solely responsible for the views expressed in the article. 


\section{Abstract \\ Striking at the Roots of Crime: The Impact of Welfare Spending on Crime During the Great Depression}

The Great Depression of the 1930s led contemporaries to worry that people hit by hard times would turn to crime in their efforts to survive. Franklin Roosevelt argued that the unprecedented and massive expansion in relief efforts "struck at the roots of crime" by providing subsistence income to needy families. After constructing a panel data set for 81 large American cities for the years 1930 through 1940, we estimate the impact of relief spending by all levels of government on crime rates. The analysis suggests that a ten percent increase in relief spending during the 1930s lowered property crime by roughly 1.5 percent. By limiting the amount of free time for relief recipients, work relief was more effective than direct relief in reducing crime. More generally, our results indicate that social insurance, which tends to be understudied in economic analyses of crime, should be more explicitly and more carefully incorporated into the analysis of temporal and spatial variations in criminal activity. 


\section{Striking at the Roots of Crime: \\ The Impact of Welfare Spending on Crime During the Great Depression}

[T] hrough a broad program of social welfare, we struck at the very roots of crime itself.... Our citizens who have been out of work in the last six years have not needed to steal in order to keep from starving. Of course, when we instituted those [New Deal] activities we did not have in mind merely the narrow purpose of preventing crime. However, nobody who knows how demoralizing the effects of enforced idleness may be, will be inclined to doubt that crime prevention has been an important by-product of our effort to provide our needy unemployed citizens with the opportunity to earn by honest work at least the bare necessities of life.

Franklin D. Roosevelt, April 17, $1939^{1}$

\section{Introduction}

Social reformers during many periods in American history have suggested that social welfare spending offers one means of deterring crime by providing people with adequate resources so they have less incentive to turn to crime. A large body of research on modern criminality suggests that increases in police spending and improvements in employment opportunities aid in reducing crime rates. ${ }^{2}$ Yet, empirical analysis that carefully examines the relationship between crime rates and social welfare programs is largely missing from the economics literature. ${ }^{3}$ During the 1930 s there was dramatic variation across cities and over time in the economic shocks from the Depression and in the distribution of social welfare spending. The period therefore offers a unique opportunity to examine the effect of social insurance on deterring crime during a major economic downturn when social welfare programs likely had the potential to have their greatest impact.

We assemble a new city-level panel data set covering the period from 1930 through 1940 to examine the degree to which relief spending "struck at the very roots of crime" during the Depression. The results suggest that crime rates were negatively related with overall relief spending and that work relief, by limiting the free time of relief recipients, did more to deter crime than did direct relief. 


\section{Relief Spending During the Great Depression}

During the 1930s the economy sunk into the depths of a Depression with double-digit unemployment. There was widespread fear that the social and economic foundation of American society was crumbling. Faith in the capitalist economy was shaken as millions of unemployed Americans quickly ran through their savings. Some sought desperate means to provide for their family's subsistence. Prior to 1932 the financial responsibility for relief to people in dire circumstances was centered squarely on local governments with some specific forms of aid from the state. A number of cities provided shelter and food in almshouses, while some cities provided relatively small amounts of cash assistance and inkind aid to the poor. Faith-based charities often distributed aid (Gruber and Hungerman 2007). Private charities in a number of cities also helped administer local aid. Most states offered mothers' pensions for widows with children and workers' compensation to injured workers and some offered old-age assistance and aid to the blind. The federal government played almost no role in providing relief spending beyond some aid to veterans. ${ }^{4}$

In response to the rising unemployment rates shown in Table 1, average per capita spending on relief for public and private programs in 114 leading U.S. cities rose more than four-fold from $\$ 1.54$ to $\$ 7.42$ (in constant 1935 dollars) between 1930 and 1932. State and local governments faced increasing problems in meeting their relief obligations, while private sources of funding were hit hard by the Depression. State and local governments therefore sought assistance from the federal government. During the fall of 1932 the Hoover administration responded with \$300 million in Reconstruction Finance Corporation loans to help some cities temporarily fund their relief budgets.

Faced with national unemployment rates near 25 percent in 1933, the Roosevelt administration argued that the economy had become a national problem and thus the federal government should accept much greater responsibility for providing relief. Between 1932 and 1934, the federal government took over the vast majority of relief provision, raising its share of total relief expenditures from 2 percent to 78.9 percent (see Table 1). The surge of federal financing nearly tripled per capita relief spending in 114 major cities from $\$ 7.42$ in 1932 to $\$ 19.70$ in 1934 (1935 dollars), the first full year the federal New Deal 
was in operation. Despite significant drops in the number of people unemployed or on work relief during the rest of the decade, the per capita spending in 1935 dollars exceeded $\$ 21$ for the rest of the decade, peaking at over $\$ 28$ when unemployment spiked again in 1938. Following the practice of the period, we included emergency relief workers as unemployed. These relief workers were only partially employed because the payments they received and the working time that was offered were limited, such that the typical family on relief during the 1930 s received benefits that did not exceed 42 percent of annual manufacturing wages (see Table 1).

Gruber and Hungerman (2007) show that the rise in federal relief spending crowded out religious based private charity during the 1930s. The Baird (1942, 12 and 152) estimates of private charity for 114 cities suggest a similar story. As relief from all levels of government rose from \$262 million in 1932 to a peak of $\$ 1.38$ billion in 1938 , private relief spending fell from its peak of $\$ 59$ million in 1932 to $\$ 10.6$ million in 1938, below its 1930 level of $\$ 14.9$ million (all monetary terms expressed in constant 1935 dollars). As a result, the private share of relief spending in the 114 cities fell from 27 percent in 1930 to 18 percent in 1932 to less than 1 percent after 1935.

Between July 1933 and June 1935 the primary federal relief agency was the Federal Emergency Relief Administration (FERA). Federal FERA officials distributed funds to state governments through an opaque process in which the revealed distribution suggests that they paid attention to the level of economic distress in the state, the state's entreaties to FERA administrators, the state's own efforts to fund relief, and the political situation. ${ }^{5}$ State governments then distributed the funds internally to local governments. FERA offered both direct relief and work relief. ${ }^{6}$ Direct relief included programs that had no specific work requirements and assistance was provided in cash or in-kind, including subsistence items, such as food, shelter, clothing and household necessities, or medical care and hospitalization. Work relief, as the name connotes, required a labor contribution in return for the government assistance. FERA set a series of broad guidelines for its programs, but relied heavily on state and local officials to administer them and to determine the appropriate amounts of relief that individuals would receive. Applicants for relief applied to local offices where officials met with them personally and determined 
their eligibility for relief based on a "budget-deficit" principle. Local officials calculated the difference between the family's total income and a hypothetical budget for a family of that size and used the deficit to determine the family's direct relief benefits or the amount that would be paid for work on a FERA project. The amount of relief actually distributed to a family in many cases fell short of the budget-deficit if FERA funds in the local area were limited, as local officials sometimes decided to stretch their limited resources by funding more relief cases at less generous amounts.

In response to a harsh winter and high levels of unemployment, FERA activities were supplemented temporarily by the Civil Works Administration (CWA) work relief program from November 15, 1933, through March 1934. Large numbers on the FERA relief rolls were transferred to CWA employment, where they received wages that were not based on the budget-deficit principle, but on prevailing local market wages. At its peak the CWA employed four million workers for a short period of time. $^{7}$

In mid-1935 the Roosevelt administration redesigned the federal government's role in providing relief. The federal government continued to provide work relief for the unemployed who were “employable" through the Works Progress Administration (WPA), but returned much of the responsibility for direct relief of "unemployables" to state and local governments. Applicants for aid were certified by state and local officials, who still considered a family's budget-deficit when assessing its need for relief employment (Howard 1943, 380-403). The federal WPA then hired people from the certified rolls. Dissatisfied with its lack of control over work relief under the FERA, the WPA was administered more centrally by the federal government. Yet the WPA, like its FERA predecessor, faced a mixture of pressures as administrators decided how to distribute spending across the U.S. State and local governments lobbied for funds and federal administrators appear to have paid attention to local economic distress and political necessities (see Howard 1943, Fleck 1999b, Fishback, Kantor, and Wallis 2003, Wallis, Fishback, and Kantor 2006).

The federal government was not completely absent from providing direct relief to "unemployables," as the Social Security Act of 1935 introduced joint state-federal versions of some 
earlier state programs, such as old-age assistance, aid to dependent children (replacing mothers' pensions), and aid to the blind. Beginning in 1936, federal grants-in-aid became available on a matching basis to states administering approved plans under the Social Security Act. By the end of 1938, people in all but 8 states were receiving federal grants. The shift in focus of the federal relief efforts and the eventual reductions in federal emergency work relief programs caused the federal share of the overall relief effort to slowly decline to 57 percent by 1940 .

\section{Estimating the Effects of Relief on Criminal Behavior}

To carry out the study, we have developed a new panel data set that enables us to measure the relationships between relief spending and seven major categories of crime for 81 cities from 1930 to 1940. In 1940 the cities in the sample accounted for 33 percent of the U.S. population and included every city with more than 300,000 people and all but 13 of the cities with more than 100,000 people (a listing of cities is shown in Appendix Table 1). The U.S. Children's Bureau published annual information on spending on public relief assistance by federal, state, and local governments and private relief assistance in 114 cities for 1929 through 1935 (Winslow 1937) and the U.S. Social Security Board updated the series and carried the data forward through 1940 (Baird 1942). The public programs covered included general relief, the CWA, the FERA, the WPA, private assistance, and aid to dependent children (also mothers' pensions), aid to the blind, and old age assistance. The relief spending also includes private relief, which fell from 27 percent of total relief spending in 1930 to less than 1 percent by 1936 (Baird, $1942,12,152)$.

In 1930 the Federal Bureau of Investigation (FBI) began the Uniform Crime Reporting (UCR) system which relied on local police reports of criminal activity in their respective cities. Lawrence Rosen $(1995,228)$ describes the formation of the UCR as the "product of both a shared ideology and the structural interplay of social science, police, private philanthropy, and public administration in the 1920s. All these interests, to one degree or another, were committed to the major premise of 'social

progressivism' ... that science could improve the social health of the community." The UCR represented the first systematic attempt to statistically document crime at the local level and even today remains one 
of the main sources of data for social scientific research on crime. Since we are examining the early days of the UCR, our sample is restricted to 81 cities that led the way in reporting crimes to the FBI.

The FBI reported data on seven major crime categories: murder and nonnegligent manslaughter, rape, robbery, aggravated assault, burglary, larceny-theft, and motor vehicle theft. We consider property crimes to be robbery, burglary, larceny, and motor vehicle theft. The FBI defines robbery to be "the taking or attempt to take anything of value from the care, custody, or control of a person or persons by force or threat of force violence and/or by putting the victim in fear." The FBI classifies robbery as a violent crime, but since it is committed to obtain something of value we have included it with property crimes for the purposes of testing whether New Deal relief mitigated theft "to keep from starving.",

The quality of the data in the UCR likely varied over time as the system became more regimented and as cities became more accustomed to their new reporting roles. The use of city fixed effects and cityspecific time trends should help control for any long-run systematic reporting disparities across cities and the use of year effects should help control for nationwide differences in reporting that varied from year to year. Further, in an analysis of the quality of the UCR data in comparison with other modern sources, Boggess and Bound (1997) suggest that the trends for robbery, burglary, auto theft, and murder in the UCR tended to match the trends in other sources during the 1980s. They indicate that crime reporting by victims and, hence, recording by police are more accurate when the crimes are more serious and committed by strangers. Trends for rape, aggravated assault, and larceny tended to vary more widely across sources because larceny is the least serious of offenses and the assaults and rapes are much more likely to be perpetrated by non-strangers.

By giving unemployed workers jobs and increasing the incomes of other poor Americans, relief spending presumably decreased the incentives to commit property crimes. In Becker's economics of crime framework, a higher income or higher wages increased the opportunity cost of committing crime. ${ }^{9}$ Work relief especially had the potential to effectively divert individuals' time and interest away from property crime toward law-abiding activities. The effects of relief spending on violent crimes like murder, aggravated assault and rape are less clear to the extent that these crimes are not driven by pure 
economic motives. The relief spending potentially still might have reduced such crimes by reducing social stresses that might have contributed to more violent acts.

Without controlling for other covariates, a simple difference-in-difference scatter plot suggests that cities with relatively larger increases in relief saw their crime rates decrease relatively more. Figure 1 plots the change in the average annual per capita property crime between 1930-1932 and 1933-1940 against the change in the average annual per capita relief spending for the same periods. The coefficient of the regression line in the figure is statistically significant at the 1 percent level. The inverse relationship between crime and relief spending in this very simple analysis is striking in light of the fact that endogeneity would tend to bias the relationship in a positive direction.

To control for the multiple attributes that may have influenced crime during the 1930s, we estimate the following regression equation:

$$
C_{i t}=\beta_{0}+\beta_{1} R_{i t}+\beta_{2} X_{i t}+\gamma_{t} T+\lambda_{i} G+\theta_{i} G t+\varepsilon_{i t}
$$

$\mathrm{C}_{\mathrm{it}}$ is the number of crimes per 100,000 people in city $\mathrm{i}$ in year $\mathrm{t}, \mathrm{R}$ is either a single relief variable or a vector of spending on each relief program. $X_{\mathrm{it}}$ is a vector $(9 \times 1)$ of correlates that also were likely to influence the crime rate. Trepresents a vector $(10 \times 1)$ of year fixed effects to capture any shocks that were experienced by all cities in a specific year. $G$ is a vector $(80 \times 1)$ of city fixed effects that control for unobservable factors that did not vary over time, but varied across the cities. The G vector of city fixed effects is also interacted with time t to develop a series of city-specific time trends. The Greek symbols are coefficients or vectors of coefficients that match up with the correlates and correlate vectors. The $\mathrm{X}_{\mathrm{it}}$ vector of control variables contains per capita city police spending (in constant 1935 dollars) to control for changes in crime prevention activity. A state employment index (equal to 100 in 1929) and cityspecific per capita retail sales (in constant 1935 dollars) are included to control for general economic activity and regular employment opportunities available in each city. To help control for differences in the income distributions across cities, annual measures of the per capita number of federal income tax returns filed and the infant mortality rate are included. Individual income tax filers earned more than $\$ 2,000$ in taxable annual income and families filing taxes earned more than $\$ 5,000$, levels of income 
reached by fewer than ten percent of households nationwide during the Depression. Therefore, tax returns per capita should control for the share of the population in the upper tier of the income distribution. The inclusion of infant mortality rates helps control for the share of population in the lower tier of the income distribution because infant mortality rates tend to be higher in lower-income households (Waldmann 1992 and Kaplan et. al. 1996).

Prohibition, the ban of the sale of alcoholic beverages under the Eighteenth Amendment of the Constitution, from January 1920 through 1933 has often been associated with a rise in criminal activity in the 1920s and early 1930s. When the national ban was ended in 1933, state and local governments made the decision about whether to continue their own bans. We use a measure, created by Strumpf and Oberholzer-Gee (2002), indicating whether the county in which the city was located was "wet" and allowed the sale of alcohol. This variable enables us to control for the impact of the relaxation of prohibition in each city. In addition, two climate measures - the average monthly precipitation and the average monthly temperature in each city in each year - are added to control for any influences of temperature or precipitation on crime rates. ${ }^{10}$ The city fixed effects control for time-invariant characteristics that vary across cities and might influence crime, including the local geography and unchanging legal climate and attitudes toward crime. ${ }^{11}$ The year effects control for national-level shocks that affected all cities in that year, like changes in federal tax policy, the end of national Prohibition, technology shocks, and other factors. The city-specific time trends control for varying crime trends in each city, which might have been the result of improvements in the reporting of crime as the city had been in the UCR system longer or trends in other factors that are not measured in the data. ${ }^{12}$ The term $\varepsilon_{\mathrm{it}}$ is a random error term.

Table 2 reports a series of estimates for per capita relief spending from ten equations with crimes per 100,000 people as the dependent variable. There are four specifications for the total property crime rate, which includes the crime categories of larceny, burglary, robbery, and auto theft. Coefficients for fixed effects estimations are reported for larceny, burglary, robbery, auto theft, murder, aggravated 
assault, and rape. The t-statistic reported is based on robust standard errors that are clustered for each city. The elasticities are estimated at the means for the sample.

Roosevelt's claim that the relief programs had "struck at the roots of crime" is supported by the results in these specifications. When the property crime rate was regressed on only per capita relief, the coefficient implies that an additional per capita dollar (1935\$) of relief and public works spending was associated with a reduction in property crimes of 13.48 per 100,000 people. The coefficient is statistically significant at the 10 percent level or better in a two-tailed t-test (this will be the standard for statistical significance throughout the paper). When other correlates, fixed effects and city-specific time trends are added to reduce omitted variable bias, the statistically significant coefficient estimate is roughly the same at -13.58 and statistically significant. The elasticity of -0.154 , estimated at the means in the sample, suggests that a one percent increase in per capita relief spending was associated with a 0.154 percent reduction in property crimes. This elasticity is somewhat smaller than the elasticity of -0.2664 reported for per capita welfare spending by Zhang (1997) for 1987. Zhang estimated the effect only for a crosssection of U.S. states in 1987; therefore, he could not control for state and year fixed effects or for statespecific time trends.

A one-standard-deviation increase in per capita relief spending of $\$ 10.4$ (1935\$) during the 1930s was associated with a reduction of 140 property crimes per 100,000 people or 0.195 standard deviation of the property crime rate. A final way to show the relationship is to consider the amount of relief spending that would have been needed to eliminate one property crime. The coefficient estimate suggests that an expenditure of $\$ 7,420$ (1935\$), or $\$ 94$ thousand in year 2000 dollars, would have led to a reduction of one property crime.

Because the 1930s was the first decade in which the Uniform Crime Reports were compiled, and new cities were joining the system throughout the decade, the panel data set is unbalanced. To examine whether the inclusion or exclusion of specific city-year observations influenced the results, we re-estimate the property crime fixed effect model with a balanced panel of cities that reported crimes in each year from 1930 through 1940. The 35 cities in the balanced panel are marked with an asterisk in Appendix 
Table 1. The balanced panel is focused more on mid-size cities with populations between 100,000 and 300,000. In the unbalanced panel 43 of the 81 cities have populations over 300,000 in 1940, while only 8 of the 35 cities in the balanced panel are in that size class. As seen in Table 2, the coefficient estimate in the balanced panel is more negative with an elasticity of -0.217 .

The remainder of Table 2 shows the estimates from regressions of each type of crime on the correlates, fixed effects, and city-specific time trends. We focus on property crimes first because they are the ones most likely to be economically motivated. The negative relationship between relief spending and property crime was present for all four categories of property crime, although the robbery coefficient estimate is not statistically significant. An increase of per capita relief spending of one dollar (1935\$; or $\$ 12.68$ in $2000 \$$ ) was associated with a reduction in crimes per 100,000 people of 7.47 larcenies, 5.59 burglaries, 2.88 auto thefts, and 0.49 robberies.

The remaining crimes in the table are violent crimes, which tend to be less motivated by economic considerations, although economic problems might have led to frustrations that contributed to the crimes. An added dollar of per capita relief spending was associated with a reduction per 100,000 people of 0.06 murders and 1.76 aggravated assaults, but an increase of 0.05 rapes. $^{13}$

Another aspect of the relief spending to examine is the effect of different types of relief on criminal activity. Economic theories of the trade-offs between work, leisure, and criminal activity predict that crime rates will have a stronger negative relationship with works programs. Able-bodied men were generally not eligible for direct relief. By providing unemployed men with the opportunity for work relief, the opportunity cost of committing a crime was increased. Further, work requirements reduced the free time available to plot and commit crimes. Direct relief should also have contributed to a decrease in property crime as the increase in non-labor income (the direct relief benefit) would have increased the potential criminal's reservation wage or reservation return to committing a crime. ${ }^{14}$ The results with relief spending split into direct and work relief spending are reported in Table 3.

The results confirm the prediction that works programs would have had a stronger negative relationship with crime than did direct relief. Crime rates were more negatively related with work relief 
than with direct relief except in the balanced panel with many fewer observations. The relief programs' coefficient estimates are negative for all but the rape category. The work relief coefficient estimates are statistically significant for property crimes in the balanced and unbalanced panels, murder, and the property crime subcategories of larceny, burglary and auto theft. Except for property crimes in the balanced panel, there are no statistically significant negative relationship between direct relief and any of the crime rates at the 10-percent level. The coefficients are substantially more negative for the works spending than for direct relief in every equation but one. In the property crime equation in the balanced panel of smaller cities, the work relief and direct relief coefficient estimates were nearly the same size. In the full panel property crime equations the work relief coefficient estimate is about 2.6 times larger, in absolute value, than the direct relief coefficient. For the specific crime categories, the ratio of the estimates of works coefficient to the direct relief coefficient range from 1.3 for aggravated assaults to 3.2 for murders. By diverting relief recipients' time to work, the work relief programs appear to have reduced crime more than the direct relief programs. The phrase "idle hands are the devil's workshop" may have been an apt homily for relief programs.

During the late 1800 s and early 1900 s, a number of social reformers had argued that private charities and churches would do a better job than local governments of helping relief recipients "develop the better character" to leave the dole and become productive members of society. In the late 1800s the Charity Organization Society took over the operation of outdoor relief in a number of cities in the United States on these grounds. ${ }^{15}$ The relief data collected for the 1930s in Baird (1942) offer an opportunity to examine these claims. In Table 4 we re-estimate the models with per capita relief broken into three parts: public work relief, public direct relief, and private relief. The coefficient estimates for work relief change very little and the difference between the total direct relief coefficient estimates in Table 3 and those for public direct relief in Table 4 are very similar. The private relief coefficient estimates are larger than the work relief coefficients in the property crime regressions with the different panels and in the murder rate regression. However, only the private relief estimate in the murder rate regression is statistically significant. The elasticities and one standard deviation effects for the private relief estimates 
are substantially smaller than for the estimates for the other types of relief because the mean and standard deviation for per capita private relief were substantially lower at 33 cents and 44 cents, respectively.

\section{$\underline{\text { Instrumental Variable Analysis }}$}

There still remains a possibility that the estimation procedure that includes the correlates and fixed effects has not fully controlled for endogeneity and simultaneity. To the degree that the various levels of government used increases in crime rates as one of their signals of a greater need for relief spending, the simultaneity bias would have been positive for the relief spending coefficients. The anticipated positive bias suggests that the relationships estimated in the fixed effects analyses in Tables 2 , 3 , and 4 are smaller in absolute value than the true relationship. There also may have been omitted variable bias to the extent that our proxies for poverty do not fully control for differences in poverty levels across cities. Poverty levels were likely to have been positively correlated with both relief spending and with crime, which would impart a positive bias to the relief spending coefficients.

To examine these potential biases further, we adopt an instrumental variables (IV) approach. After controlling for the set of correlates in the analysis, the instrument must be correlated with relief spending but uncorrelated with the estimated error term of the crime regression. Since the estimation uses data from a panel of cities with year and city fixed effects, the instruments must vary over time as well as across cities. To achieve this end, we multiplied a cross-sectional variable that measures a factor influencing Roosevelt's re-election strategy by a time series variable that captures national fluctuations in per capita relief spending to create an interaction term that varies across time and space. The crosssectional political strategy variable is a measure of the city's loyalty to the Democratic party in presidential elections. We use the mean of the percentage voting for the Democratic presidential candidate between 1896 and 1928 in the city. There is little likelihood of correlation between the Democratic loyalty measure and the unobservable error in the second-stage crime rate equation. The Democratic presidential voting patterns are from a 32-year period that ended two years before the first year in our sample, thus eliminating any contemporaneous correlation. Further, we have controlled for a 
variety of measures of income and distributions of income that would be the primary channels through which the Democratic vote for president would have been correlated with the error term in the crime rate equation.

The second part of the interaction term is designed to capture the fact that the primary driver of the changes in total relief spending across time was the amount of federal money distributed across the country, but avoiding the possibility of correlation with the city's error term. Therefore, we developed a proxy for the changes in national per capita relief spending for city $i$ in year $t$ that is the total per capita spending for a group of cities outside the region where city $i$ is located that also were not included in the estimation sample because of the lack of crime information. By choosing cities outside the sample and outside city i's region, the possibility of cross-correlations with city $\mathrm{i}$ in this portion of the instrument is reduced. ${ }^{16}$ There was no national budget limit that served as a binding constraint on total relief spending, as the Roosevelt administration often drew additional funds from Congress throughout the New Deal, and budget deficits as a percentage of GDP were much lower than they are today.

A second instrument is the number of months of "extreme" wetness in each city in each year. The measure is based on the Palmer Drought Severity Index, which ranges from -6 to +6 . Periods of extreme wetness are associated with values above 4 . The purpose of the instrument is to capture extreme periods when the rainfall was so strong that it brought work relief projects to a halt in ways that could not have been offset during the rest of the year. The projects generally were able to operate under a broad range of normal rainfall conditions. When the rainfall hit extreme levels, however, the outdoor projects were halted. Given that there were limits on how many hours relief workers could work each month, it was not easy to make up the lost time during the rest of the year. Approximately 6 percent of the cityyears in the sample experienced a period of extreme wetness, in some cases as many as 3 to 5 months of extreme wetness. A question still remains as to whether such heavy rainfall might have influenced crime rates as well. It has been documented that rainfall and temperature can influence crime and we have already included measures of average rainfall and temperature over the year to capture these effects in the 
second-stage crime regressions. We see no reason, a priori, that extreme rainfall will have an additional effect on the crime rate after controlling for the continuous measures of average rainfall.

Since there is no way to measure the unobservable error in the second-stage crime regression, we can never know for certain that our instruments are uncorrelated with the true error. We can at least examine whether the instruments are uncorrelated with the estimated error from the IV analysis using standard over-identification tests. The results of Hansen j-tests are consistent with the hypothesis that the identifying instruments have not been inappropriately omitted from the second-stage crime equation using 20 percent as the rejection level.

As seen in Table 5, the coefficient of the interaction between national relief spending and the Democratic loyalty measure is negative with a t-statistic of -7.44 in the first-stage relief equation. The political economy studies of New Deal spending generally find a mixed set of results for the loyalty variable, suggesting that long-term Democratic support was generally not rewarded. These results are more strongly negative, but they are also one of the few sets of results that examine the situation in a panel setting. Meanwhile, the extreme wetness coefficient estimate, as expected, is negative with a tstatistics of -3.26 in the first-stage spending equation. The F-statistic for the hypothesis that the identifying instruments both have zero coefficients is 30.95 in the first-stage relief equation. The Kleibergen-Papp Wald rank statistic of 30.95 (an adjusted version of the Cragg-Donald statistic when errors are robustly estimated) exceeds Stock and Yogo's critical value of 19.93. The comparison implies that if one is willing to accept a maximal weak instrument bias of 10 percent, the hypothesis of weak instrument bias is rejected. ${ }^{17}$

Comparisons of the IV coefficient estimates in Table 6 with the estimates in Table 2 do not show a clear pattern. The IV relief coefficient estimates in the overall property crime, burglary, robbery, murder, and aggravated assault equations are more negative than the Table 2 coefficients, but the IV estimates are less negative for larcenies and auto thefts. We did not report IV estimates for the balanced panel property crimes and the rapes due to weak instrument problems. The IV coefficient estimates are generally less precisely estimated, and only the aggravated assaults and burglary estimates are statistically 
significant. This raises the question as to whether there are endogeneity or simultaneity biases in the coefficients in Table 2. When we perform the standard Hausman test for endogeneity, which only is meaningful if the identifying instruments are strong and are uncorrelated with the true error in the crime rate equation, we cannot reject the hypothesis of no endogeneity in all but the aggravated assault analysis.

To perform IV analysis for the distinct effects of direct and work relief spending, we used a similar strategy. The instruments include the extreme wetness measure and two interaction terms. Each uses the cross-sectional Democratic loyalty measure as part of the interaction. The loyalty term is then interacted with the changes in work relief spending from outside the sample and outside the region where city $i$ is located to create an instrument for work relief spending. For direct relief the loyalty term is interacted with the changes in direct relief spending outside city i's region and outside the sample.

To effectively identify the distinct effects of work relief and direct relief, it is important that the identifying instruments have different relationships with work relief than they do with direct relief. As seen in Table 5, the coefficient for the work relief/loyalty interaction term is negative with a t-value of -7.61 in the work relief equation and positive in the direct relief equation. Similarly, the coefficient for the direct relief/loyalty interaction term is negative with a t-value of -5.59 in the direct relief equation and positive in the direct relief equation. The severe wetness measure is negative and statistically significant in only the work relief first-stage, which is expected because severe weather would have only affected work relief opportunities and not direct relief. The F-statistics for the two first-stage equations are 21.54 and 11.11. The Kleibergen-Paap rank Wald F-statistics of 11 exceeds the Stock-Yogo critical value for 15 percent maximal weak instrument bias of 8.18. The Hansen $\mathrm{j}$-statistic p-value is 0.946 , which is consistent with the hypothesis that the instruments are not correlated with the estimated errors in the final stage crime equation.

Comparisons of the results in Tables 3 and 7 show the same pattern that work relief spending had a more negative effect on most crime rates than did direct relief. Except for aggravated assaults none of the direct relief coefficient estimates are statistically significant. As was the case for the comparisons between the coefficient estimates in Tables 2 and 6, the comparisons of the IV coefficient estimates in 
Table 7 to the estimates in Table 3 show that the direction of the differences varies by crime. The Hausman tests for endogeneity cannot reject the hypothesis that there was no endogeneity for each crime rate regression except for aggravated assaults. We did not perform IV estimates for the three-way split of relief spending because we could not find instruments that were strong in each first-stage equation but not strong in the other equations to allow us to separately identify the effects of each type of relief.

\section{Other Correlates}

The coefficients for the other correlates in Table 5 offer some insights on the relationships between crime and other measures of economic activity. Economic theory predicts that increased employment opportunities would have reduced crime by raising legal incomes and thus increasing the opportunity cost of committing crime and also reducing the time available for criminal activity. Steven Raphael and Rudolf Winter-Ebmer (2001) found a significantly positive effect of unemployment on property crime rates in more recent decades. Eric D. Gould, Bruce A. Weinberg, and David B. Mustard (2002) found that the unemployment rate and wages of unskilled men played a significant role in crime trends between 1979 and 1997. Increased retail sales, a strong proxy for income, potentially have conflicting effects. They might reduce crime by raising the incomes of legal alternatives to crime, but crime might be increased to the extent that the rewards from crime are raised by the availability of targets with higher incomes. Another measure of this potential "loot effect" is the number of tax returns per capita, which captures the share of the population with incomes that would put them in the top 5-10 percent of the U.S. population in the 1930s.

The coefficient estimates of the state employment index in Table 5 are negative and statistically significant, as predicted. The coefficients in the property crime regressions are roughly -16 , which imply elasticities of roughly -1.00 . The one-standard-deviation effects suggest that a one-standard deviation improvement in state employment rates was associated with a 0.253 standard deviation reduction in crime rates. The one-standard-deviation effect is roughly similar in size to one-standand-deviation effects of 0.13 to 0.424 for the relationship between unemployment rates and property crime rates that we have 
calculated from Raphael and Winter-Ebmer's (2001) estimates from a panel of American states from 1976 to $1997 .^{18}$

The effect of higher incomes on crime rates are not strong in this sample. The coefficient estimates for the share of high-income people - tax returns per capita - are negative, but the elasticity of -0.0465 is small and the coefficient is not statistically insignificant. Meanwhile, the coefficients for retail sales per capita are very small and not statistically significant. There is some evidence that more poverty is associated with higher property crime rates because the coefficient of infant mortality, which is associated with poverty, is positive, although statistically significant only in the IV regressions. The coefficient estimate implies an elasticity of 0.25 .

The relationship between crime rates and police spending per capita was positive, although only statistically significant in the instrumental variable regressions. The positive relationship was likely driven by endogeneity and simultaneity bias, as local governments raised police spending in response to increased criminal activity. ${ }^{19}$

\section{Conclusion}

The economic downturn associated with the Great Depression pushed millions of American workers and their families into personal economic crises. With legal employment opportunities significantly limited by the Depression, some families who faced desperate circumstances for the first time likely turned to illegal means for subsistence. The unprecedented relief spending accompanying the New Deal helped alleviate distress by providing work and income opportunities for the unemployed. One salutary effect of the expansion in relief programs was a reduction in the crime rate. Our empirical analysis suggests that New Deal relief lowered property crime in a statistically and economically significant way. The estimates suggest that a 10 percent increase in per capita relief spending during the Great Depression was associated with a 1.5 percent reduction in property crime rates.

Work relief was a prominent feature of Depression era relief, although it is relatively uncommon today. Economic theory suggests that the reduction of free time associated with work relief would have 
made it more effective at reducing crime rates than relief payments without a work requirement. The results here are consistent with this prediction, as the bulk of the effect of total per capita relief spending on reducing crimes can be attributed to the work relief component.

At various times in the history of American welfare policy, there have been claims that relief provided by private organizations had more salutary effects than did government-run relief because the private organizations did more to "build character" among the recipients. The results for the major cities in the 1930s show relatively small and statistically significant elasticities of crime rates with respect to privately administered relief.

It appears that Roosevelt's intuition expressed in his 1939 speech, quoted at the beginning of the paper, was accurate. New Deal relief spending, so carefully targeted at the lower end of the income distribution during a major economic crisis, appears to have "struck at the very roots of crime" during the 1930s. The results in this paper add to a list of beneficial effects associated with New Deal spending on public works and relief. Other recent studies suggest that relief expenditures were associated with lower infant mortality, fewer suicides, fewer deaths from some forms of disease, higher birth rates, more inmigration, and expansions in economic activity. ${ }^{20}$

More generally, our results indicate that social insurance, which tends to be understudied in the economic analyses of crime, should be more explicitly and more carefully incorporated into the analysis of temporal and spatial variations in criminal activity. Our results offer limited insight into the modern worries about a culture of poverty and crime associated with expansions in the generosity of long-term welfare programs. After all, the Great Depression was a major crisis that led to the introduction of many of the features of the modern welfare system. The New Deal experience says much more about the impact of social insurance in settings where people are confronted with an extraordinary economic misfortune. Our results suggest that for such people who are suddenly faced with greater temptation to steal, the availability of social insurance helps tilt the balance in favor of lawful behavior. 


\section{FOOTNOTES}

${ }^{1}$ Franklin D. Roosevelt, “Address at the National Parole Conference,” Washington, DC, April 17, 1939. Accessible at The American Presidency Project, http://www.presidency.ucsb.edu.

${ }^{2}$ When identifying the effect of unemployment on crime, Cook and Zarkin (1985) point out that there are a number of omitted variables that may vary with the business cycle that might affect crime, yet are not always easily included in empirical studies of crime. The factors that can lead to omitted-variable bias include measures of legitimate employment opportunities, the presence of criminal opportunities, the consumption of drugs, alcohol, or guns, and the quantity and effectiveness of the police and criminal justice system.

${ }^{3}$ In two recent articles that provide a survey of the crime literature from an economics perspective (Witte and Witt 2001 and Levitt 2004), social insurance was ignored as a potential determinant of international or temporal variations in crime. Some notable exceptions in the literature include Zhang (1997), which is one of the only studies in economics to explicitly model and empirically measure the impact of welfare payments. He found that public housing assistance had much greater effects on crime reduction than such programs as Aid to Families with Dependent Children, Medicaid, or the school lunch program. However, Zhang estimated the model on a cross-section of states for the year 1987 and thus could not employ any of the panel data techniques used to control for a wide range of omitted variables. Hashimoto (1987) examines the link between increases in the minimum wage with teenage crime. Hansen and Machin (2002) explore the effect of the minimum wage in the UK and find that areas that had relatively more low-wage workers who benefited from the minimum wage floor experienced reduced crime. Lochner and Moretti (2004) and Lochner (2004) explore the link between educational attainment and skill level and crime. They find significant social returns to programs that contribute to educational attainment. Donohue and Siegelman (1998) consider the counterfactual case of reallocating money away from prisons and into targeted preschool programs. They contend that crime could be reduced without greater social spending if large-scale increases in prison expenditures were 
diverted to preschool interventions. Finally, in terms of other types of social policy that may influence crime, see Donahue and Levitt (2001) who argue that legalized abortion may account for up to 50 percent of the recent drop in crime.

Sociologists have taken up the question of how welfare influences crime, but, like economists, have not delved deeply into the question. See DeFronzo (1983), Devine, Sheley, and Smith (1988), and Hannon and DeFronzo (1998) for empirical studies of the link between public assistance and crime.

${ }^{4}$ See Winslow (1937), Baird (1942), Skocpol (1992, ch. 2), Clark, Craig, and Wilson (2003), and Fishback and Thomasson (2006, 2:709).

${ }^{5}$ For an empirical analysis of the distribution of FERA grants, see Fleck (1999b) and Fishback, Kantor and Wallis (2003). For discussions of the administrative details of relief provision, see Brown (1940), Howard (1943), and U.S. National Resources Planning Board (1942).

${ }^{6}$ Our relief measure includes some privately administered relief spending, which accounted for roughly one-quarter of relief spending prior to 1933, but less than one percent thereafter. Privately administered relief in many cases came from government sources. More detailed breakdowns for urban areas can be found in Baird (1942). Several programs that might be considered public assistance were not included in the reported relief data. For example, FERA emergency education, student aid, the Civilian Conservation Corps (CCC), the National Youth Administration, and transient programs were omitted. Pandiani (1982) argues that the CCC potentially contributed significantly to crime reduction in cities because the program targeted poor young men. We have not found city-level information on the CCC but we have explored including per capita state-level information on the CCC in the work relief spending variable. We have also explored adding state information on earnings under the Public Works Administration (PWA), which tended to hire more skilled workers. Including spending per capita in these programs - 60 cents from the PWA and 40 cents from the CCC $(1935 \$)$ - leads to qualitative results that are generally the same as those reported below.

${ }^{7}$ For discussions of the FERA and CWA policies, see Brown (1940, 218-98) and U.S. National 
Resources Planning Board (1942, 26-97).

${ }^{8}$ Burglary is defined as the "unlawful entry of a structure to commit a felony or theft." Larcenytheft is the "unlawful taking ... of property from possession ... of another ... in which no use of force, violence, or fraud occurs." Motor vehicle theft is self-explanatory.

${ }^{9}$ See Zhang (1997) for an explicit theoretical model of how welfare payments influence the decision to commit crime. Grogger (1998) provides a theoretical analysis of the incentive effects of wages on criminal behavior. Whether we view New Deal relief as an income supplement or as a means of raising reservation wages of individuals, the theoretical models predict the same outcome: relief should diminish the incentive to commit property crime.

${ }^{10}$ See, for example, Field (1992), Cohn and Rotton (2000), Rotton and Cohn (2003), and Simister and Cooper (2005).

${ }^{11}$ Glaeser, Sacerdote, and Scheinkman (1996) find that there is high variance across cities in crime rates and that much of the variance is explained by social interactions.

${ }^{12}$ As an alternative to the city-specific time trends, we have estimated the model with time trends for demographic changes by including a series of variables that have values from the 1930 and 1940 Census and are interpolated between Census years on a straight-line. The variables we incorporated included percent foreign-born, percent black, percent illiterate, and the percent aged 10 to 34 . The cityspecific time trends approach is a more flexible means of controlling for such trends and an OaxacaGeissler $(2003,376)$ F-test suggests that the city-specific time trends control for more factors than do the interpolated demographic variables. None of the estimated coefficients for the demographic variables were statistically significantly different from zero.

${ }^{13}$ Fishback, Haines and Kantor (2007) had information on homicides and suicides from the Bureau of the Census volumes on Mortality Statistics, an alternative source to the FBI's Uniform Crime Reports. Their estimates suggest that expenditures of approximately \$29 million 
(2000\$) were associated with eliminating a homicide and \$13 million associated with eliminating a suicide.

${ }^{14}$ See Raphael and Winter-Ebmer (2001) for labor theoretic analysis of the effects of work opportunities and non-labor income on crime that are directly applicable to the predicted effects of work relief and direct relief.

${ }^{15}$ See Ziliak (1997) for an extended discussion of the past and modern versions of this argument and for an empirical test of the success of the shift from public to private charity through the Charity Organization Society in the late 1800 s.

${ }^{16}$ There were 31 cities for which we had relief spending information but are not included in the sample because of a lack of crime data. We have also performed the estimation using the per capita relief spending in all cities in the sample outside the region of city $i$, and the basic results are the same.

${ }^{17}$ See Stock and Yogo (2002), Stock, Wright, and Yogo (2002), Kleibergen and Paap (2006) and Kleibergen (forthcoming).

${ }^{18}$ Raphael and Winter-Ebmer (2001) estimated a model with the natural log of the property crime rate per 100,000 as a function of the unemployment rate. The standard deviation for the unemployment rate was .02 and for the property crime rate was 1158.20 and the coefficients in Table 2 ranged from 1.6 to 5. We calculated the one-standard-deviation effect by starting with the antilog of their sample mean for the crime rate at 4674.81, which equals 8.4494. Multiplying the coefficient (1.6) times the standard deviation of the unemployment rate (.02) gave a value of 0.0469 , which was added to 8.4494 to get 8.49684. We then took the anti-log to get the change in the crime rate of 224.47 , which is 0.1938 standard deviations.

${ }^{19}$ For the results of IV analysis of the impact of police activity on modern crime rates, see Levitt (1997, 2002) and McCrary (2002).

${ }^{20}$ See Fishback, Haines, and Kantor (2007) and Fishback, Horrace, and Kantor (2005 and 2006). 


\section{REFERENCES}

Baird, Enid, Public and Private Aid in 116 Urban Areas, 1929-38, with Supplement for 1939 and 1940, U.S. Federal Security Agency, Social Security Board, Public Assistance Report No. 3 (Washington, DC: Government Printing Office, 1942).

Becker, Gary S., "Crime and Punishment: An Economic Approach," Journal of Political Economy 76 (Mar.-Apr. 1968), 169-217.

Boggess, Scott and John Bound, "Did Criminal Activity Increase During the 1980s? Comparisons Across Data Sources," Social Science Quarterly 78 (September 1997), 725-39.

Carter, Susan, et. al., Historical Statistics of the United States, Millennial Edition (New York: Cambridge University Press, 2006).

Clark, Robert L., Lee A. Craig, and Jack W. Wilson, A History of Public Sector Pensions in the United States (Philadelphia: University of Pennsylvania Press, 2003).

Cohn, Ellen G., and James Rotton, "Weather, Seasonal Trends and Property Crimes in Minneapolis, 1987-1988: A Moderator-Variable Time-Series Analysis of Routine Activities," Journal of Environmental Psychology 20 (Sept. 2000), 257-72.

Cook, Philip J., and Gary A. Zarkin, "Crime and the Business Cycle," Journal of Legal Studies 14 (Jan. 1985), 115-28.

DeFronzo, James, "Economic Assistance to Impoverished Americans: Relationship to Incidence of Crime," Criminology 21 (Feb. 1983), 119-36.

Devine, Joel A., Joseph F. Sheley, and M. Dwayne Smith, "Macroeconomic and Social-Control Policy Influences on Crime Rate Changes, 1948-1985," American Sociological Review 53 (June 1988), 407-20.

Donohue, John J. III, and Steven D. Levitt, “The Impact of Legalized Abortion on Crime,” Quarterly Journal of Economics 116 (May 2001), 379-420.

Donohue, John J. III and Peter Siegelman, "Allocating Resources Among Prisons and Social Programs in the Battle Against Crime," Journal of Legal Studies 27 (Jan. 1998), 1-45.

Field, Simon, "The Effect of Temperature on Crime," British Journal of Criminology 32 (Summer 1992), 340-51.

Fishback, Price V., Michael R. Haines, and Shawn Kantor, "Births, Deaths, and New Deal Relief During the Great Depression," Review of Economics and Statistics 89 (February 2007), pp. 1-14.

Fishback, Price V., William C. Horrace, and Shawn Kantor, "Did New Deal Grant Programs Stimulate Local Economies? A Study of Federal Grants and Retail Sales During the Great Depression," Journal of Economic History 65 (March 2005), 36-71.

"The Impact of New Deal Expenditures on Mobility During the Great Depression," Explorations in Economic History, 43 (April 2006), 179-222.

Fishback, Price, Shawn Kantor, and John Wallis. "Can the New Deal's Three R's Be Rehabilitated? A Program-by-Program, County-by-County Analysis." Explorations in Economic History (October 2003); 278-307.

Fishback, Price and Melissa Thomasson. "Social Welfare: 1929 to the Present," in Historical Statistics of the United States, Millennial Edition, edited by Susan Carter, et. al. (New York: Cambridge University Press, 2006).

Fleck, Robert, "The Value of the Vote: A Model and Test of the Effects of Turnout on Distributive Policy," Economic Inquiry 37 (Oct. 1999), 609-23.

Glaeser, Edward, Bruce Sacerdote, and Jose Scheinkman. "Crime and Social Interactions," Quarterly Journal of Economics 111 (May 1996): 507-548.

Gould, Eric D., Bruce A. Weinberg, and David B. Mustard, "Crime Rates and Local Labor Market Opportunities in the United States: 1979-1997," Review of Economics and Statistics 84 (Feb. 2002), 45-61.

Grogger, Jeff, "Market Wages and Youth Crime," Journal of Labor Economics 16 (Oct. 1998), 756-91. 
Gruber, Jonathan and Daniel Hungerman. "Faith-Based Charity and Crowd-Out During the Great Depression.” Journal of Public Economics 91 (2007): 1043-1069.

Hannon, Lance, and James DeFronzo, "The Truly Disadvantaged, Public Assistance, and Crime," Social Problems 45 (Aug., 1998), 383-92.

Hansen, Kirstine, and Stephen Machin, "Spatial Crime Patterns and the Introduction of the UK Minimum Wage," Oxford Bulletin of Economics and Statistics 64 (Dec. 2002), 677-97.

Hashimoto, Masanori, “The Minimum Wage Law and Youth Crimes: Times-Series Evidence,” Journal of Law \& Economics 30 (Oct. 1987), 443-64.

Howard, Donald S., The WPA and Federal Relief Policy (New York: Russell Sage Foundation, 1943).

Kaplan, George A., Elsie R. Pamuk, John W. Lynch, Richard D. Cohen, and Jennifer L. Balfour, "Inequality in Income and Mortality in the United States: Analysis of Mortality and Potential Pathways," British Medical Journal 312 (April 20, 1996), 999-1003.

Kleibergen, F. "Generalizing weak instrument robust statistics towards multiple parameters, unrestricted covariance matrices and identification statistics," Journal of Econometrics (forthcoming).

Kleibergen, F., and R. Paap, "Generalized reduced rank tests using the singular value decomposition." Journal of Econometrics 133 (2006), 97-126.

Levitt, Steven D., "Using Electoral Cycles in Police Hiring to Estimate the Effect of Police on Crime," American Economic Review 87 (June 1997), 270-90.

, Using Electoral Cycles in Police Hiring to Estimate the Effects of Police on Crime: Reply," American Economic Review 92 (Sept. 2002), 1244-50.

"Understanding Why Crime Fell in the 1990s: Four Factors that Explain the Decline and Six that Do Not," Journal of Economic Perspectives 18 (Winter 2004), 163-90.

McCrary, Justin. "Do Electoral Cycles in Police Hiring Really Help Us Estimate the Effect of Police on Crime? Comment." American Economic Review 92 (June 2002): 1236-43.

Oaxaca Ronald and Iris Geisler. "Fixed Effects Models with Time Invariatn Variation: A Theoretical Note." Economics Letters 80 (2003): 373-77.

Pandiani, John A, "The Crime Control Corps: An Invisible New Deal Program," British Journal of Sociology 33 (Sept. 1982), 348-58.

Rand McNally, Commercial Atlas and Marketing Guide (New York: Rand McNally, 1934, 1935, 1938, 1939, 1943).

Raphael, Steven and Rudolf Winter-Ebmer, "Identifying the Effect of Unemployment on Crime," Journal of Law and Economics 64, (April 2001), 259-283.

Rosen, Lawrence, "The Creation of the Uniform Crime Reports: The Role of Social Science," Social Science History 19 (Summer 1995), 215-38.

Rotton, James, and Ellen G. Cohn, "Global Warming and U.S. Crime Rates: An Application of Routine Activity Theory," Environment and Behavior 35 (Nov. 2003), 802-25.

Simister, John, and Cary Cooper, "Thermal Stress in the U.S.A.: Effects on Violence and on Employee Behaviour," Stress and Health 21 (Feb. 2005), 3-15.

Skocpol, Theda, Protecting Soldiers and Mothers: The Political Origins of Social Policy in the United States (Cambridge, MA: Belknap Press, 1992).

Stock, James H., and Motohiro Yogo, "Testing for Weak Instruments in Linear IV Regression," National Bureau of Economic Research Technical Working Paper No. 0284, October 2002.

Stock, James H., Jonathan Wright, and Motohiro Yogo, "A Survey of Weak Instruments and Weak Identification in Generalized Methods of Moments," Journal of Business and Economic Statistics 20 (October 2002b), 518-29.

Strumpf, Koleman and Felix Oberholzer-Gee. "Endogenous Policy Decentralization: Testing the Central Tenet of Economic Federalism.” Journal of Political Economy 110 (February 2002), 1-36.

U.S. Bureau of Census, Financial Statistics of Cities (Washington, DC: Government Printing Office, various years). 
U.S. Bureau of Census, Historical Statistics of the United States: Colonial Times to 1970 (Washington, DC: Government Printing Office, 1975).

U.S. Bureau of Internal Revenue, Statistics of Income for 1930 (Washington, DC: GPO, 1932).

U.S. Bureau of Internal Revenue, "Number of Individual Income Tax Returns for 1935 by States, Counties, Cities, and Towns," mimeo, 1935.

U.S. Bureau of Internal Revenue, "Number of Individual Income Tax Returns for 1937 by States, Counties, Cities, and Towns," mimeo, 1939.

U.S. Bureau of Internal Revenue, "Number of Individual Income Tax Returns for 1938 by States, Counties, Cities, and Towns," mimeo, 1940.

US Bureau of Internal Revenue, "Number of Individual Income Tax Returns for 1939 by States, Counties, Cities, and Towns," Mimeo, 1941.

U. S. Bureau of Economic Analysis, State Personal Income: 1929-1987 (Washington, DC: Government Printing Office, 1989).

U.S. Department of Commerce, Bureau of Foreign and Domestic Commerce, Consumer Market Data Handbook, 1936 (Washington, DC: Government Printing Office, 1936)

U.S. Department of Commerce, Bureau of Foreign and Domestic Commerce, Consumer Market Data Handbook, 1939. (Washington, DC: Government Printing Office, 1939).

U.S. Federal Bureau of Investigation, Uniform Crime Reports (Washington, DC: Government Printing Office, various years).

U.S. National Resources Planning Board, Security, Work, and Relief Policies (Washington, DC: Government Printing Office, 1942).

Waldmann, Robert J., "Income Distribution and Infant Mortality," Quarterly Journal of Economics 107 (Nov. 1992), 1284-302.

Wallis, John Joseph, "Employment in the Great Depression: New Data and Hypotheses," Explorations in Economic History 26 (Jan. 1989), 45-72.

Wallis, John Joseph, Price Fishback, and Shawn Kantor, "Politics, Relief, and Reform: Roosevelt's Efforts to Control Corruption and Manipulation During the New Deal," in Corruption and Reform edited by Edward Glaeser and Claudia Goldin (Chicago: University of Chicago Press, 2006), 34372.

Witte, Ann Dryden and Robert Witt, "What We Spend and What We Get: Public and Private Provision of Crime Prevention and Criminal Justice," Fiscal Studies 22 (2001), 1-40.

Winslow, Emma A., Trends in Different Types of Public and Private Relief in Urban Areas, 1929-35, U.S. Department of Labor, Children's Bureau Publication No. 237 (Washington, DC: Government Printing Office, 1937).

Zhang, Junsen, "The Effect of Welfare Programs on Criminal Behavior: A Theoretical and Empirical Analysis," Economic Inquiry 35 (Jan. 1997), 120-37.

Ziliak, Stephen. "Kicking the Malthusian Vice: Lessons from the Abolition of "Welfare" in the Late Nineteenth Century," Quarterly Review of Economics and Finance 37 (Summer 1997), 449-68. 
Table 1

Trends in Relief Spending for 114 U.S. Cities, 1930 to 1940

\begin{tabular}{ccccc}
\hline Year & $\begin{array}{c}\text { Unemp. } \\
\text { Rate } \\
\text { (Entire } \\
\text { U.S.) }\end{array}$ & $\begin{array}{c}\text { Per } \\
\text { capita } \\
\text { relief } \\
\text { spending } \\
\mathbf{( 1 9 3 5 ~ \$ )}\end{array}$ & $\begin{array}{c}\text { Ratio of } \\
\text { Average } \\
\text { annual relief } \\
\text { benefits to } \\
\text { annual } \\
\text { manufacturing } \\
\text { earnings }\end{array}$ & $\begin{array}{c}\text { Federal } \\
\text { share of } \\
\text { relief } \\
\text { spending }\end{array}$ \\
\hline 1930 & 9.0 & $\$ 1.54$ & & \\
1931 & 16.3 & $\$ 3.72$ & & \\
1932 & 24.1 & $\$ 7.42$ & & $2.1 \%$ \\
1933 & 25.2 & $\$ 12.21$ & 0.217 & 51.8 \\
1934 & 22.0 & $\$ 19.70$ & 0.312 & 78.9 \\
1935 & 20.3 & $\$ 20.97$ & 0.333 & 78.9 \\
1936 & 17.0 & $\$ 25.39$ & 0.424 & 74.7 \\
1937 & 14.3 & $\$ 21.47$ & 0.376 & 72.1 \\
1938 & 19.1 & $\$ 28.61$ & 0.393 & 62.0 \\
1939 & 17.2 & $\$ 26.02$ & 0.383 & 62.5 \\
1940 & 14.6 & $\$ 21.75$ & 0.349 & 57.4 \\
\hline
\end{tabular}

Notes: Per capita relief spending represents a population-weighted average for 114 cities. Relief per capita is the total of all direct relief, work relief and private relief funds. Direct relief includes direct relief under the FERA, by state and local governments, and categorical assistance for dependent children, old-age assistance, and aid to the blind. Prior to 1935 the categorical assistance categories refer to funds provided by state and local governments through mothers' pensions, old-age pensions, and state aid to the blind. Work relief includes payments to workers on state and local government, FERA, CWA, and WPA projects. Private relief is the value of relief funds from private and public sources administered by private agencies. Average annual relief benefits were calculated as the ratio of total relief expenditures per number of households on relief. The data source reported the information monthly and we summed across months for the annual estimate. The 1940 data were only reported through June, so we doubled the amount reported to derive the annual estimate. We do not have information on the federal share of relief prior to 1932, but it was probably similar to 1932's value. The federal share of relief information includes the cost of administering the programs. The 1932 federal figure includes $\$ 3.7$ million in federal workers' compensation payments. The state and local expenditures include workers' compensation, general relief, old-age assistance, aid to dependent children, aid to the blind, and state shares of unemployment compensation, WPA, CWA, and the National Youth Administration.

Sources: Relief spending data are reported in Baird (1942) and Winslow (1937). Population data are from Haines and ICPSR (2005). Linear interpolation was used to estimate population for years between 1930 and 1940 censuses. For federal share of relief spending, see U.S. National Resources Planning Board (1942, 292, 598-603). Average relief expenditures per household were calculated from data on households receiving relief and total expenditures on relief in U.S. National Resources Planning Board (1942, 557-61). Average annual manufacturing earnings are from U.S. Bureau of the Census Bureau (1975, 166). Unemployment rates for the entire United States are calculated from Series Ba470, Ba474, and Ba477 in Carter, et. al. (2006, 2:82-83). Federal emergency relief workers were included as unemployed in this calculation. Per capita relief spending was adjusted to 1935 dollars by using the 
Consumer Price Index with 1967 as the base year in series E-135 in Bureau of Census $(1975,210-1)$ to adjust the dollars to 1967 values and then multiplying by .411 the value of the CPI in 1935 . 
Table 2

OLS Results for Per Capita Relief Spending Variable in Crime Rate Equations

\begin{tabular}{|c|c|c|c|c|}
\hline $\begin{array}{l}\text { Estimation (dep. } \\
\text { var. is crime rate } \\
\text { per } 100,000 \\
\text { people) }\end{array}$ & $\begin{array}{l}\text { Coeff. } \\
t \text {-stat. }\end{array}$ & Elast. & OSD & $\begin{array}{c}\text { Dollars of relief needed to } \\
\text { prevent one crime }\end{array}$ \\
\hline & & & & $1935 \$$ \\
\hline
\end{tabular}

\begin{tabular}{lrrrrr}
\hline ORDINARY LEAST SQUARES & & & \\
Property Crimes - & -13.478 & -0.153 & -0.194 & $\$ 94,082$ & $\$ 7,420$ \\
No Correlates & -3.5 & & & & \\
Property Crimes - & -14.928 & -0.170 & -0.215 & $\$ 84,942$ & $\$ 6,699$ \\
Correlates & -2.78 & & & & \\
Included & & & & &
\end{tabular}

CORRELATES AND CITY FIXED EFFECTS, YEAR EFFECTS AND CITY TRENDS INCLUDED

\begin{tabular}{|c|c|c|c|c|c|}
\hline Property Crimes & $\begin{array}{r}-13.584 \\
-2.29\end{array}$ & -0.154 & -0.195 & $\$ 93,346$ & $\$ 7,362$ \\
\hline $\begin{array}{l}\text { Property Crimes-- } \\
\text { Balanced Panel }^{\mathrm{a}}\end{array}$ & $\begin{array}{r}-19.130 \\
-2.61\end{array}$ & -0.217 & -0.275 & $\$ 66,283$ & $\$ 5,227$ \\
\hline Larcenies & $\begin{array}{r}-7.473 \\
-1.88\end{array}$ & -0.132 & -0.148 & $\$ 169,678$ & $\$ 13,382$ \\
\hline Burglaries & $\begin{array}{r}-5.594 \\
-2.48\end{array}$ & -0.212 & -0.244 & $\$ 226,657$ & $\$ 17,875$ \\
\hline Robberies & $\begin{array}{r}-0.493 \\
-1.13\end{array}$ & -0.103 & -0.076 & $\$ 2,570,877$ & $\$ 202,751$ \\
\hline Auto Thefts & $\begin{array}{r}-2.880 \\
-1.71\end{array}$ & -0.149 & -0.172 & $\$ 440,336$ & $\$ 34,727$ \\
\hline Murders & $\begin{array}{r}-0.063 \\
-1.39\end{array}$ & -0.135 & -0.076 & $\$ 20,162,855$ & $\$ 1,590,131$ \\
\hline $\begin{array}{l}\text { Aggravated } \\
\text { Assaults }\end{array}$ & $\begin{array}{r}-1.763 \\
-1.06\end{array}$ & -0.499 & -0.192 & $\$ 719,236$ & $\$ 56,722$ \\
\hline Rapes & $\begin{array}{r}0.047 \\
0.34\end{array}$ & 0.123 & 0.083 & $\mathrm{NA}^{\mathrm{b}}$ & $\mathrm{NA}^{\mathrm{b}}$ \\
\hline
\end{tabular}

\footnotetext{
${ }^{a}$ A listing of the cities in the balanced panel and unbalanced panels is reported in Appendix Table 1.

${ }^{\mathrm{b}}$ NA means not applicable because coefficient estimate is positive.
} 
Notes: Each row represents a different estimation specification. Property crimes are the sum of larcenies, robberies, burglaries, and auto thefts. The dependent variables are crimes per 100,000 people. Whitecorrected standard errors clustered by city are in italics below each coefficient. The fixed effects estimates for the property crime regression are reported in Table 5. The elasticity is calculated at the mean of the sample. The OSD is the number of standard deviations by which the crime rate changes with an increase of one standard deviation of per capita relief spending. All specifications except the first row regression include the following correlates: per capita police spending, a state employment index, per capita retail sales in the county where the city is located, per capita tax returns in the county, an indicator for the elimination of the prohibition of alcohol at the local level, average precipitation for the year, average daily temperature, general fertility rate, and the infant mortality rate. All monetary values are expressed in constant 1935 dollars. All fixed effects and city-specific time trend regressions include dummy variables for all cities but the excluded city (Bridgeport, CT), time trends for all cities, dummy variables for all years except the excluded year 1930. The number of observations is 780 for property crimes and larcenies, 781 for robberies, burglaries, and auto thefts, 779 for murders, 780 for aggregated assaults, and 463 for rapes. Rape information was not reported after 1936.

Sources: For the sources of the relief spending data, see Table 1. Relief per capita is the total of all direct relief, work relief and private relief funds. The crime data were collected from the U.S. Federal Bureau of Investigation (various years). The state employment index is from Wallis (1989) and the demographic data are from Haines and ICPSR (2005). Police spending was collected from U.S. Bureau of Census, Financial Statistics (various years). We were able to collect retail sales information for the counties in which the cities were located for 1929, 1933, 1935, and 1939. Retail sales from 1929 and 1939 are from the amended ICPSR file and retail sales for 1933 and 1935 are from U.S. Department of Commerce, Bureau of Foreign and Domestic Commerce $(1936,1939)$. The population estimate used to create the per capita measure was based on straight-line interpolations between 1920, 1930, and 1940 data from Haines and ICPSR (2005). We interpolated values of per capita retail sales in the intervening years using estimates of state personal income from the U.S. Bureau of Economic Analysis (1989). For each year between 1930 and 1940, we divided state personal income by an estimate of state population. Then to interpolate per capita retail sales between the benchmark years of 1929, 1933, 1935, and 1939, we used a formula such as the following for 1931: $R_{31}=R_{29}+\left(R_{33}-R_{29}\right) *\left(S_{31}-S_{29}\right) /\left(S_{33}-S_{29}\right)$, where $R$ is per capita retail sales in the appropriate year for the county in which the city was located and $\mathrm{S}$ is per capita state personal income in the same year. Fertility and infant mortality data are from the U.S. Bureau of the Census, Birth, Stillbirth and Infant Mortality Statistics (various years) and in data sets used by Fishback, Haines, and Kantor (2007), available at http://economics.eller.arizona.edu/faculty/Fishback.aspx. Rainfall and temperature data are from the National Climatic Data Center (NCDR). Text files of the data were accessed from ftp://ftp.ncdc.noaa.gov/pub/data/cirs/ (August 2003). The NCDR reports historical monthly data by climate division within each state, so each city's climate information pertains to its respective climate division. If a city was located within two or more divisions, climate information was calculated as the average across the climate divisions in which the city was located. Koleman Strumpf provided gave us the information on the probability that the city had eliminated Prohibition (Strumpf and Oberholzer-Gee 2002). The number of tax returns in 1930, 1933, 1937, 1938, and 1940 are respectively from the U.S. Bureau of Internal Revenue (1932, 1935, 1939, 1940, and 1941); for 1931, 1932, 1935, 1936, and 1940 are respectively from Rand McNally (1934, 1935, 1938, 1939, 1943); and for 1934 the source is U.S. Department of Commerce, Bureau of Foreign and Domestic Commerce (1939). The relief spending, retail sales per capita, and police spending measures were adjusted to 1935 dollars by using the Consumer Price Index with 1967 as the base year in series E-135 in Bureau of Census $(1975,210-1)$ to adjust the dollars to 1967 values and then multiplying by .411 the value of the CPI in 1935 . Year 1935 dollars can be roughly converted to year 2000 dollars by multiplying by 12.68 . 